\title{
Benign familial fleck retina
}

\author{
SURA F. SABEL AISH AND BASEM DAJANI \\ From the Jordan University Hospital
}

SUMmaRY A family with a benign form of fleck retina is describad. Seven out of 10 siblings were affected. The consanguinious parents were both normal. The fundi were massively invaded by lesions which appeared as discrete, bright white or yellow flecks situated well behind the retinal blood vessels. The macula was always free. Fluorescein studies revealed a healthy macula and retinal and choroidal blood vessels. The relationship of this benign form to the other forms of fleck retina is discussed.

Massive mosaic hyaline excrescences along the cuticular layer of Bruch's membrane, leading to the appearance of multiple deep yellow to yellowish white lesions of variable size and shape in the fundi have been well known for more than a century. ${ }^{1-3}$ Many forms of this condition have been described with different findings, prognosis, and inheritance. ${ }^{4-15}$

Krill ${ }^{16}$ regarded all these conditions as fleck retina diseases. He then classified them into 4 groups: fundus albipunctatus, fundus flavimaculatus, familial drusens, and fleck retina of Kandori. This classification with subgrouping according to the severity of the condition seemed to bring order into the confusion that had lasted for a century.

In this paper we present a family with flecked retina, with typical fundoscopy picture and normal visual findings. We suggest they belong to a fifth group-benign familial fleck retina.

\section{Patients and methods}

This was an Arab Palestinian family residing in Amman-Jordan. There were 10 children. The parents are first cousins. All 12 members of the family were studied. The parents had normal vision and fundi. Seven out of 10 children had flecked retina (Fig. 1). The affected children had undergone the following ophthalmic investigations: Refraction tests and assessment of visual acuities, dark adaptometry, central and peripheral visual fields, fundoscopy along with white light photography, and fluorescein angiography. Examination of the patients included a full blood picture; blood

Correspondence to Dr S. F. Sabel Aish, Jordan University Hospital, PO Box 13046, Amman-Jordan.

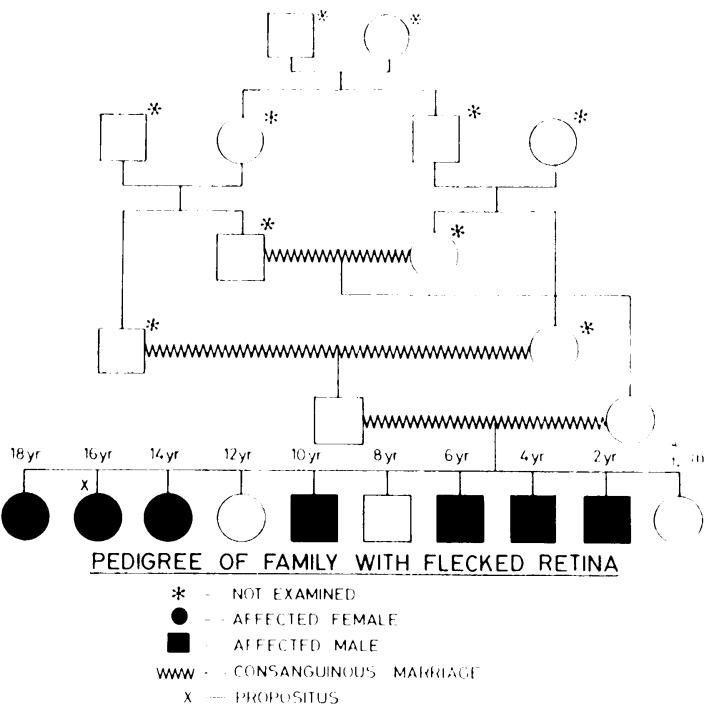

Fig. 1 The pedigree of the family.

sugar, cholesterol; protein electrophoresis; and skull $x$-rays.

\section{CASE 1}

The propositus was a 16-year-old girl who presented in 1977 with headaches. She gave no history of ophthalmic or systemic disease.

On examination her visual acuities were $6 / 18$ corrected to $6 / 6$ with -1.00 DS in either eye. The anterior segments of both eyes were normal, and the intraocular pressures were within normal limits. Central and peripheral visual fields did not show any abnormalities, and dark adaptometry was normal. Fundoscopy showed that in both eyes 


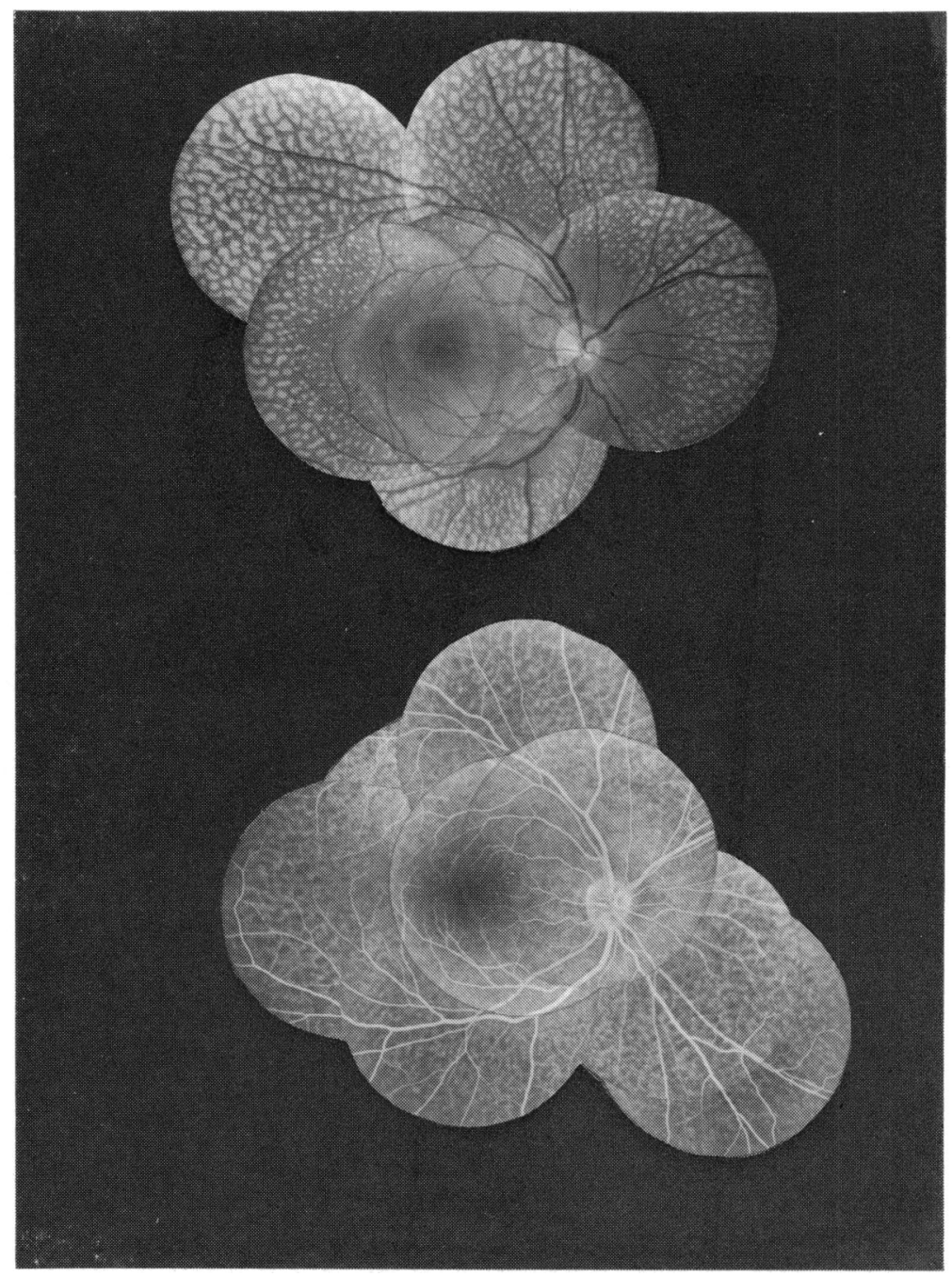

Fig. 2 Above: White light photograph demonstrating fleck: retinal dystrophy in case 1 (the propositus). Central areas are spared. Below: Fluorescein angiography of the same eye. Notice that the macula is the only nonhyperfluorescent area. the fundi were invaded by an enormous number of bright white and sometimes yellowish white flecks of variable size and configuration, arranged in a concentric pattern around the posterior fundus and sparing the optic disc, macula, papillomacular area as well as 1-2 disc diameters circular region surrounding the disc and macula. They spread everywhere in the equator and mid and extreme periphery of fundus. The more centrally located flecks appeared sparse, small, round, and dot-like. Others of larger size in the equatorial and peripheral areas varied in shape, being, round, elongate, pisciform, star-shaped, and sometimes circular. The flecks were always discrete, well defined, with almost sinuous margins and a flat or prominent surface. They appeared to be solid and well behind the retinal vascular tree. Throughout the fundus they showed the same mosaic appearance. They spared no area in the periphery. No pigmentary disturbances, calcification or conglomeration was observed, nor were choroidal vessels observed.

Follow-up 1 year later gave the same fundoscopy findings, with $6 / 6$ corrected visual acuity in either eye. Headaches had disappeared, visual fields were again normal, and there was no delay in dark adaptation.

Fluorescein angiography carried out at this time showed that apart from the macula the whole fundus was hyperfluorescent, including the central areas which appeared free of flecks on fundoscopy and white light photography. This indicated there was no close correlation between the site of the 
Fig. 3 Above: Plain fundus composite photograph illustrating the distribution of flecks in case 2. The flecks involve more central areas than those in case 1. Below: Fluorescein angiography to the same eye.

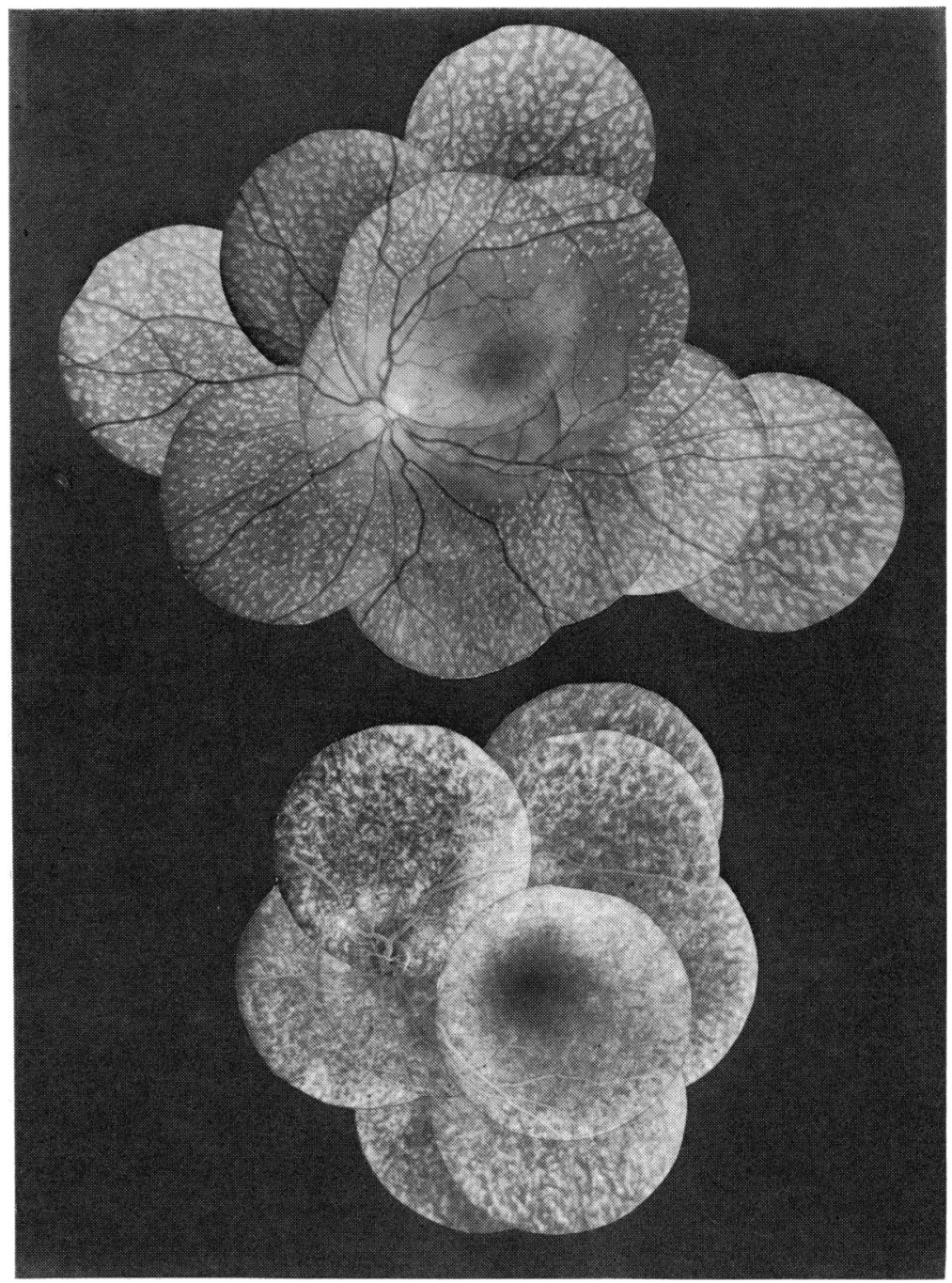

flecks and the hyperfluorescent areas, particularly in the central part of the fundus (Fig. 2).

\section{CASE 2}

The eldest sister of the propositus was 18 years old. She gave no history of systemic or ophthalmic trouble.

Visual acuity in both eyes was $6 / 6$. Her visual fields and dark adaptometry were normal. The fundi were extensively invaded by flecks like those seen in case 1. The disc, macula, and paramacular area bordered by the upper and lower temporal retinal vascular branches were the only areas that were spared (Fig. 3). Small, round, dot-like flecks were distributed nasally above and below the disc, while the equatorial and midperipheral areas of the fundi were invaded by much larger fleck lesions with irregular configurations, mainly longitudinal in shape. The most peripheral parts of the fundus were invaded mainly by linear flecks. The results of fluorescein angiography were comparable to those seen in the propositus. The only nonfluorescent area was the macula (Fig. 3).

\section{CASE 3}

A 14-year-old boy, brother of the propositus. His corrected visual acuities were $6 / 6$. His visual fields were normal, and he did not show any defect in dark adaptation. The fundi were very extensively invaded by fleck lesions, comparable in shape and size to those in the propositus. But in this case, apart from the disc and macula, no other areas were 


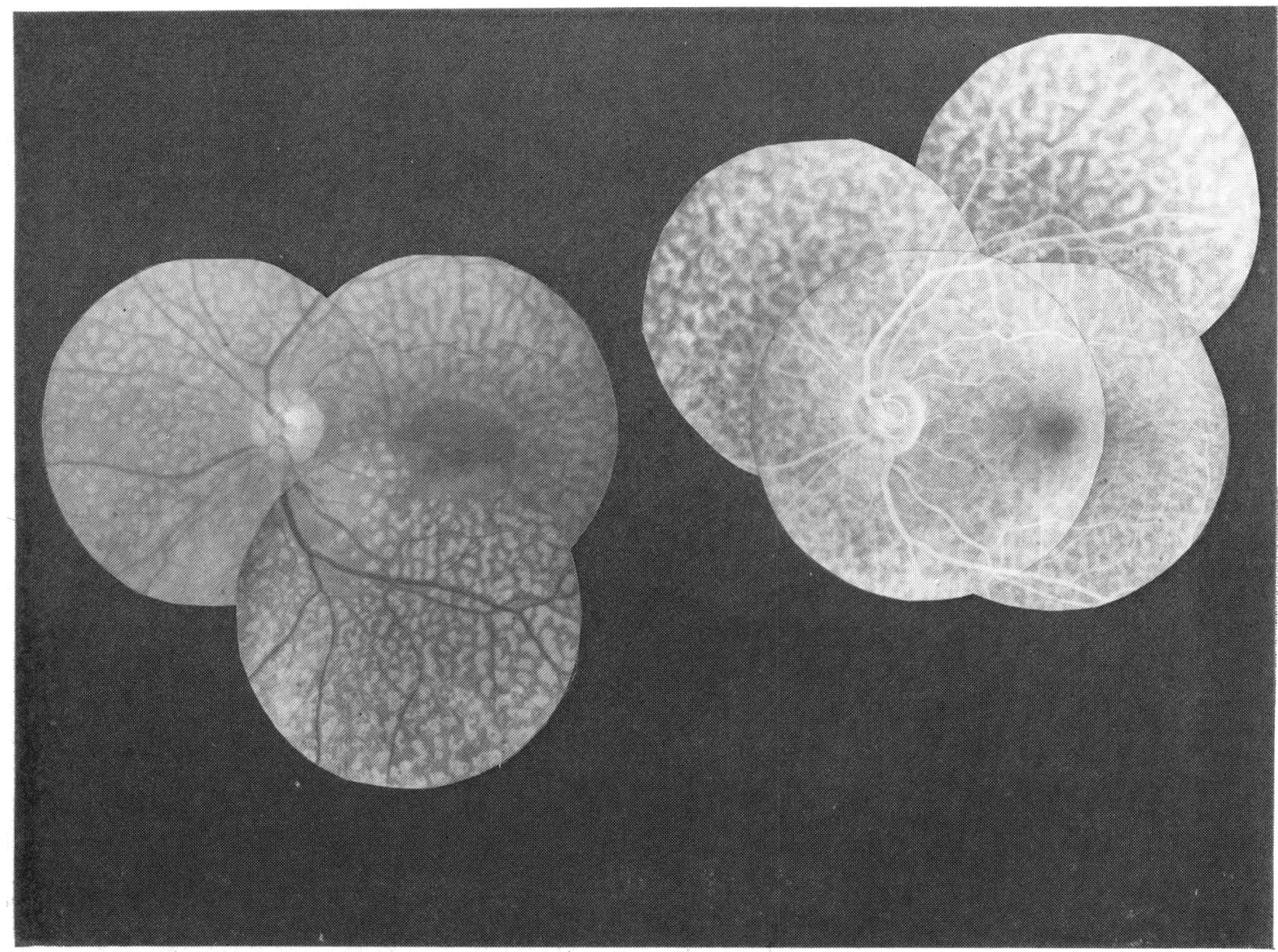

Fig. 4 Left: White light fundus composite photograph of the left eye of case 3. Right: Fluorescein angiography of the same eye.

spared (Fig. 4). As in the previous cases, fluorescein angiography showed hyperfluorescence of the whole fundi apart from the macula itself, with a normal vascular tree (Fig. 4).

\section{CASE 4}

A 12-year-old boy, brother of the propositus. This child was also healthy, with $6 / 6$ visual acuities and normal visual fields and dark adaptometry. Both his eye grounds were affected with fleck lesions comparable in shape, size, and distribution to those in the propositus, as seen by fur,doscopy, fundus photography, and fluorescein angiography (Fig. 5).

\section{CASE 5}

A 6-year-old brother of the propositus. He had 6/6 uncorrected visual acuities with normal visual fields and dark adaptometry. Only the mid and extreme periphery of the eye grounds were invaded by small, dot-like, round fleck lesions. Some appeared to be of the same shape as those found in the pre- vious cases but never of the same size. The disc, macula, and retinal as well as choroidal blood vessels were normal. Fluorescein angiography revealed a rather uniform hyperfluorescent fundus apart from the fleck-free macular area (Fig. 6).

\section{CASE 6}

A 4-year-old boy, brother of the propositus. As in the previous cases he had $6 / 6$ vision in both eyes, and examination of the anterior segments of both eyes showed nothing abnormal. Fundoscopy of both eyes revealed symmetrical involvement, with fine fleck lesions scattered everywhere beyond the central fundus. The flecks appeared immature in comparison with those seen in the older sisters and brothers. Discrete and sparse along the central border of the involved areas, they were mainly round in shape. Fluorescein angiography revealed hyperfluorescent fundi except for the macula itself. The retinal and choroidal blood vessels were normal (Fig. 7). 
Fig. 5 Above: White light fundus photography. Below: Fluorescein angiography to left eye of case 4. Here the pattern and distribution of flecks are rather similar to those of the propositus.

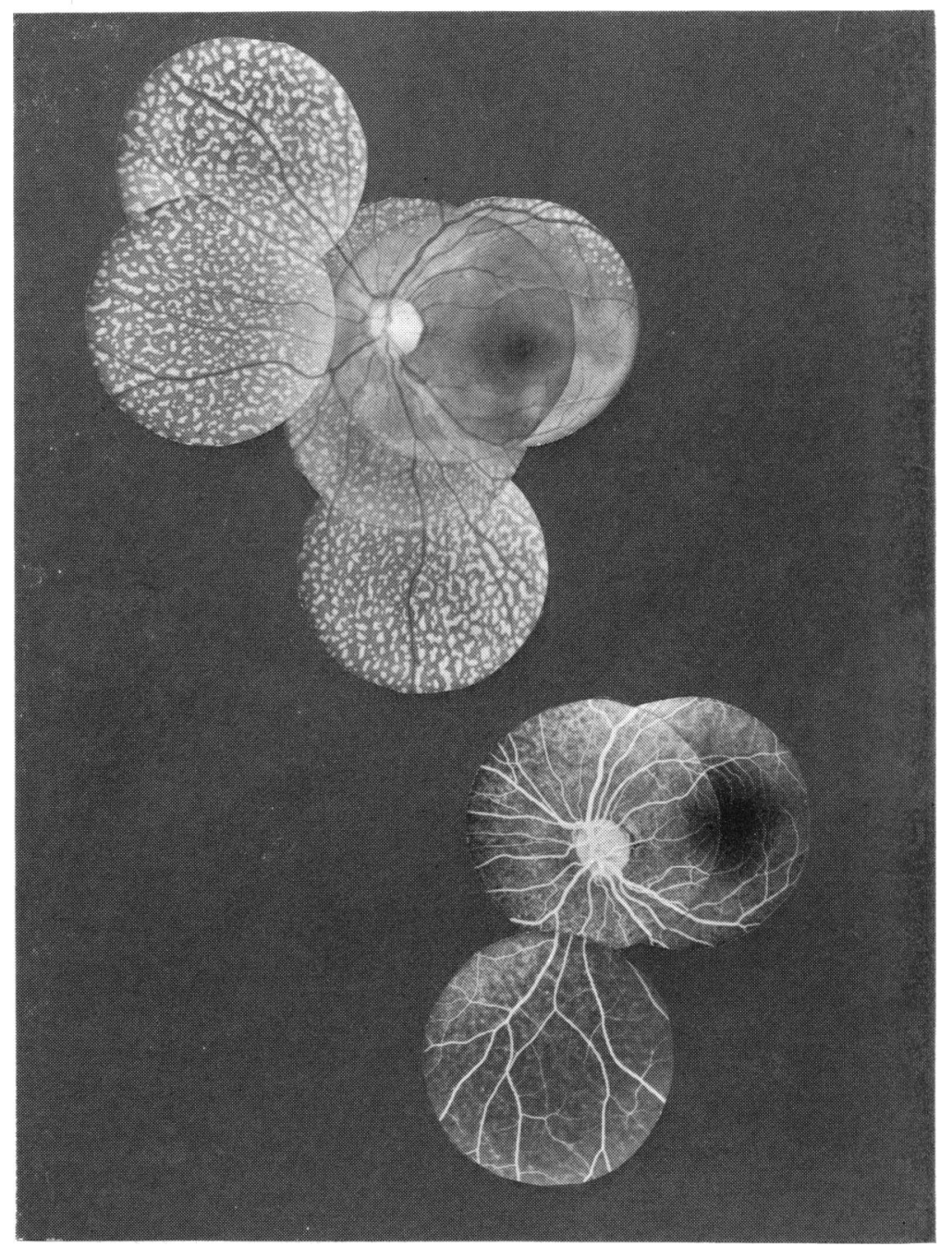

and linear. No vascular changes in either retina or choroid and no abnormalities in the central fundus were observed. Nor could pigmentary disturbances or secondary calcifications be seen among the fleck-like lesions. Apart from some differences in size and shape of the flecks and slight variations in the pattern of their distribution in the juxtapapillary area, these 7 cases seem to constitute a uniform fleck retina dystrophy.

Clinically there was no night blindness or any delay in dark adaptation. The fundal lesions in the younger patients were clearly immature when judged by their size, density, concentration, and shape in comparison with those of the older patients. However, the findings at fluorescein angiography did not differ with age of patient. These observa-
The 7 cases presented here are characterised by multiple whitish or yellowish white fleck-like deposits deeply situated in the retina well behind the retinal vascular tree. They varied in size and configuration, being round, pisciform, star-shaped, 


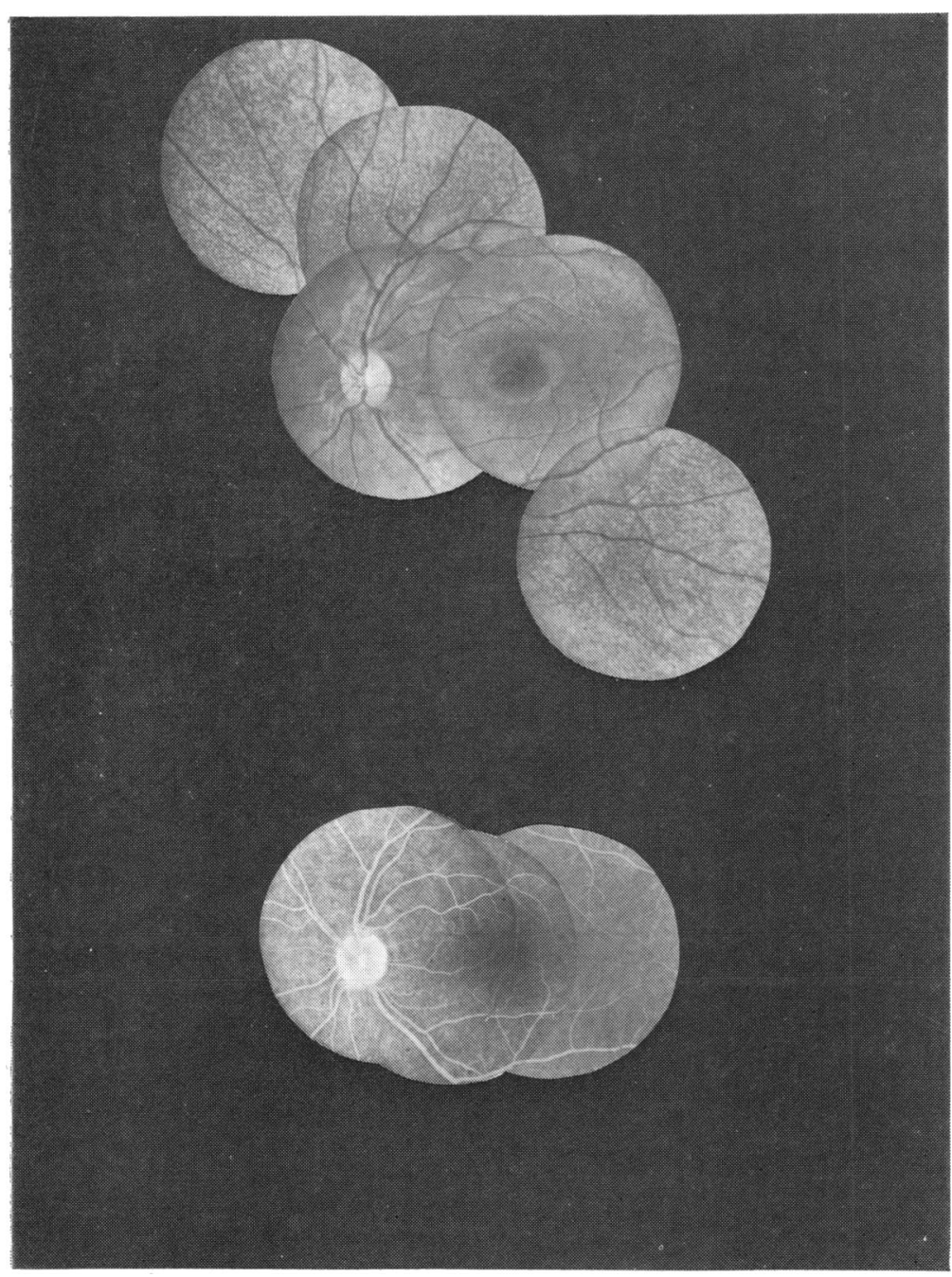

Fig. 6 Above: White light photography. Below: Fluorescein angiography. Left eye, case 5. Notice the fine immature flecks which are studded in the paracentral and peripheral area.

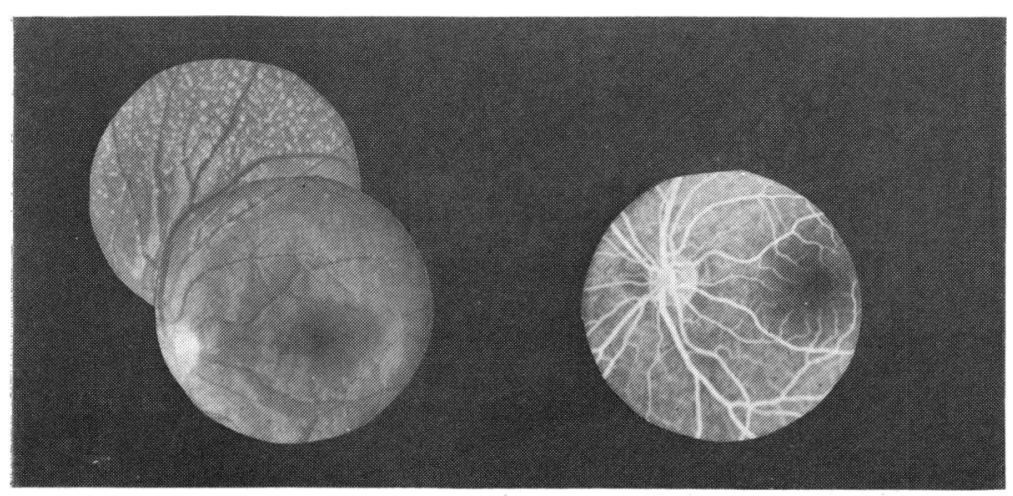

Fig. 7 Left: White light fundus photograph of left eye in case 6, showing the small fine flecks dystrophy extending beyond the central areas. Right: Fluorescein angiography of same eye. 
tions, together with the fact that there was hyperfluorescence of the fleck-free area as seen with fundoscopy and white light photography, suggest that involvement of Bruch's membrane antedates the appearance of the flecks.

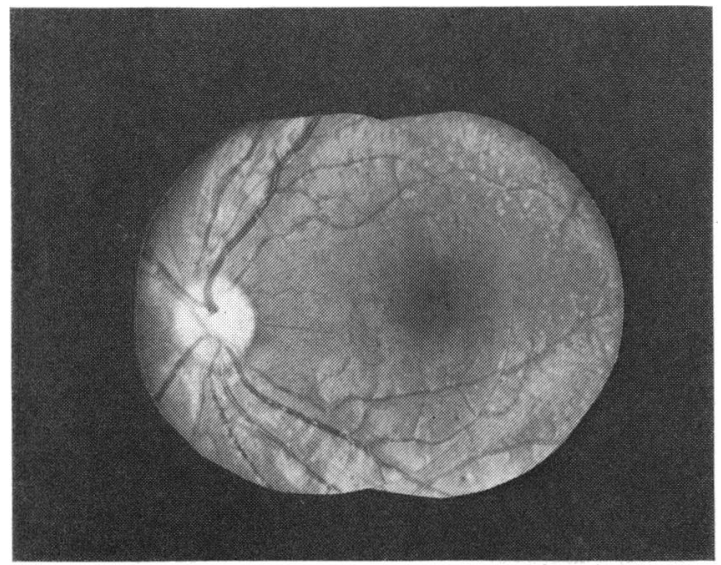

Fig. 8 Fundus white light photograph showing some discrete, fine, dot-like flecks scattered in the peripheral fundus of left eye in case 7.
The main features of the different types of flecked retina disorders reported in the literature are summarised in Table 1 . We consider the family reported here to be a separate entity, benign familial fleck retina. In contrast to all previously reported cases of fleck retina disorders our cases showed no disturbance of visual functions attributable to the disorder during a 3-years follow-up. It is obvious that our family cannot be considered as familial drusen or fundus flavimaculatus. The macular involvement, calcifications, choroidal involvement, and visual function disturbances reported in these conditions are different from what was seen in our family.

The distribution of the flecks in our cases may be similar to that of fundus albipunctatus, but their shape is different. In addition, the fact that none of our cases had any disturbance of visual function puts them in a separate entity. When compared to cases of the fleck retina of Kandori our cases show more extensive involvement of the fundus, with flecks of different shape and size that show no conglomeration.

We suggest that benign familial fleck retina is inherited as an autosomal recessive condition. This is

Table 1 Classification of fleck retina disorders

\begin{tabular}{|c|c|c|c|}
\hline Fleck retina disease & Changes in fundi & Functional disturbances & Mode of inheritance \\
\hline Fundus albipunctatus 461820 & $\begin{array}{l}\text { Discrete uniform white dots. } \\
\text { Distribution: over the whole } \\
\text { fundus greatest density at } \\
\text { midperiphery. No macular } \\
\text { involvement. No pigmentary } \\
\text { disturbances or secondary } \\
\text { calcification }\end{array}$ & $\begin{array}{l}\text { Night blindness. Dark } \\
\text { adaptation: normal, slow or } \\
\text { monofunctional (only cone } \\
\text { threshold) }\end{array}$ & $\begin{array}{l}\text { Autosomal recessive } \\
\text { Autosomal dominant }{ }^{23}\end{array}$ \\
\hline Fundus flavimaculatus 91118 & $\begin{array}{l}\text { Round, linear, or pisciform } \\
\text { lesions. Distribution: limited } \\
\text { to the posterior pole, or } \\
\text { extends to the equator. Macula } \\
\text { is involved. Network atrophy } \\
\text { of retinal pigment epithelium. } \\
\text { Choroidal vascular atrophy }\end{array}$ & $\begin{array}{l}\text { Central visual loss, colour } \\
\text { vision loss, photophobia, } \\
\text { paracentral scotoma, slow dark } \\
\text { adaptation }\end{array}$ & Autosomal recessive ${ }^{12142425}$ \\
\hline Familial drusen 2122 & $\begin{array}{l}\text { Round or oval lesions in almost } \\
\text { grape-like clusters. Distribution: } \\
\text { concentrated in the posterior } \\
\text { polar region. Pigmentary } \\
\text { disturbances and secondary } \\
\text { calcifications. Macula is almost } \\
\text { always involved, may appear } \\
\text { oedematous or haemorrhagic }\end{array}$ & $\begin{array}{l}\text { Loss of vision during } \\
\text { progressive stages, central } \\
\text { scotoma slow dark } \\
\text { adaptation }\end{array}$ & Autosomal dominant ${ }^{182226-28}$ \\
\hline Fleck retina of Kandori ${ }^{7}{ }^{30}$ & $\begin{array}{l}\text { Irregular flecks with great } \\
\text { variability in size. Distribution: } \\
\text { in the equatorial or between the } \\
\text { equatorial and macular region } \\
\text { with tendency for confluence. } \\
\text { No macular lesions. Disturbance } \\
\text { of pigment epithelium }\end{array}$ & $\begin{array}{l}\text { Some night blindness. Initially } \\
\text { delayed dark adaptation, } \\
\text { recovers to normal value after } \\
30-40 \text { minutes in the dark }\end{array}$ & Autosomal recessive \\
\hline Benign familial fleck retina & $\begin{array}{l}\text { Round, linear, or pisciform. } \\
\text { Distribution: in the whole } \\
\text { fundus except the disc and } \\
\text { macula. No macular lesions. } \\
\text { No tendency for confluence. } \\
\text { No pigmentary disturbances }\end{array}$ & $\begin{array}{l}\text { No disturbance of visual } \\
\text { function (no symptoms) }\end{array}$ & Autosomal recessive \\
\hline
\end{tabular}


supported by the fact that both sexes were involved and that both parents were free of the disease.

\section{References}

${ }^{1}$ Wedl C. Grundzuge der pathologischen Histologie, Wien: Gerold, 1854: 825.

${ }^{2}$ Donders FC. Beiträge zur pathologischen Anatomie des Auges. Albrecht von Graefes Arch Klin Ophthalmol 1855; 1: 106.

${ }^{3}$ Muller H. Untersuchungen über die glashaute des Auges, insbesondere die glaslamelle der Choroidea und ihre senilen Veranderungen. Albrecht von Graefes Arch Klin Ophthalmol 1856; 2: 1-63.

${ }^{4}$ Mooren A. Fünf Lustren ophthalmologischer Wirksamkeit. Wiesbaden: Bergmann, 1882: 311.

${ }^{5}$ Doyne RW. Peculiar condition of choroiditis occurring in several members of the same family. Trans Ophthalmol Soc UK 1899; 19: 71 .

${ }^{6}$ Lauber $\mathrm{H}$. Die sigenaunte Retinitis punctata albescens Klin Monatsbl Augenheilkd 1910; 48: 133-48.

${ }^{7}$ Kandori F. Very rare cases of congenital non-progressive night blindness with fleck retina. Jpn J Ophthalmol 1959; 13: 384-6.

${ }^{8}$ Brini A. Fundus flavimaculatus. Bull Soc Ophthalmol Fr 1966; 66: 222-39.

${ }^{9}$ Franceschetti A, Francois J. Fundus flavimaculatus. Arch Ophthalmol (Paris) 1965; 25: 505-30.

${ }^{10}$ Carr RE. Fundus flavimaculatus. Arch Ophthalmol 1965; 74: 163-8.

${ }^{11}$ Ernest JT, Krill AE. Fluorescein studies in fundus flavimaculatus and drusen. Am J Ophthalmol 1966; 62: 1-6.

${ }^{12}$ Kempt H, Amalric P, Remky H. Fundus flavimaculatus. Klin Monatsbl Augenheilkd 1967; 150: 625-36.

${ }^{13}$ Deutman AF. The Hereditary Dystrophies of the Posterior Pole. Assen: Van Gorcum, 1971: 484.

"Babel J. Le fundus flavimaculatus. Arch Ophthalmol (Paris) 1972; 32: 109-21.
${ }^{15}$ Newell FW, Krill AE, Farkas TC. Drusen and fundus flavimaculatus: clinical, functional and histological characteristics. Trans Am Acad Ophthalmol Otolaryngol 1972; 76: 88-100.

${ }^{18}$ Krill AE, Klien BA. Flecked retina syndrome. Arch Ophthalmol 1965; 74: 496-508.

${ }^{17}$ Krill AE. Hereditary Retinal and Choroidal Diseases: Flecked Retina Diseases. Hagerstown: Harper and Row, 1877: 2: 739-819.

${ }^{18}$ Duke-Elder S. Diseases of the retina. System of Ophthalmology. St Louis: Mosby, 1967: 10.

${ }^{19}$ Francois J. Fundus flavimaculatus. Ophthalmologica (Basel) 1970; 160: 105-9.

${ }^{20}$ Franceschetti A, Francois J, Babel J. Les heredo-degenerescences Chorioretinennes (degenerescences tapeto-retinennes) Paris: Masson, 1963: 1.

${ }^{21}$ Pataias J. Honigwabenahnliche der Netzhaut als nosologische Einheit. Ophthalmologica (Basel) 1957; 134: 101-4.

${ }^{22}$ Pearce WC. Doyne's honeycomb retinal degeneration. Br J Ophthalmol 1968; 52: 73-8.

${ }^{23}$ Krill AE, Folk MR. Retinitis punctata albescens. A functional evaluation of unusual case. Am J Ophthalmol 1962; 53: $450-4$.

${ }^{24}$ Brown N, Hill DW. Fundus flavimaculatus. Two familial cases with macular degeneration. $\mathrm{Br} J$ Ophthalmol 1968; 52: 849-52.

${ }^{25} \mathrm{Klien}$ BA, Krill AE. Fundus flavimaculatus: clinical, functional, and histopathological observations. Am J Ophthalmol 1967; 64: 3-23.

${ }^{26}$ Doyne RW. A note on family choroiditis. Trans Ophthalmol Soc UK 1910; 30: 93-274.

${ }^{27}$ Evans PJ. Five cases of familial retinal dystrophy. Trans Ophthalmol Soc UK 1950; 70: 13-58.

${ }^{28}$ Fuchs A. Drusen of the lamina vitrea. Am J Ophthalmol $1956 ; 41$ : 840-6.

${ }^{29}$ Deutman AE, Jansen LM. Dominantly inherited drusen of Bruch's membrane. Br J Ophthalmol 1970; 54: 373-82.

${ }^{30}$ Kandori F, Tamai A, Kurimoto S, Fukunaga K. Fleck retina. Am J Ophthalmol 1972; 73: 673-85. 